\title{
The Rule of Surrender in International Humanitarian LaW
}

\author{
Russell Buchan*
}

Under international humanitarian law it is prohibited to make the object of attack a person who has surrendered. This article explores the circumstances in which the act of surrender is effective under international humanitarian law and examines, in particular, how surrender can be achieved in practical terms during land warfare in the context of international and non-international armed conflict. First, the article situates surrender within its broader historical and theoretical setting, tracing its legal development as a rule of conventional and customary international humanitarian law and arguing that its crystallisation as a law of war derives from the lack of military necessity to directly target persons who have placed themselves outside the theatre of armed conflict, and that such conduct is unacceptable from a humanitarian perspective. Second, after a careful examination of state practice, the article proposes a three-stage test for determining whether persons have surrendered under international humanitarian law: (1) Have persons attempting to surrender engaged in a positive act which clearly reveals that they no longer intend to participate in hostilities? (2) Is it reasonable in the circumstances prevailing at the time for the opposing force to discern the offer of surrender? and (3) Have surrendered persons unconditionally submitted to the authority of their captor?

Keywords: surrender, international humanitarian law, hors de combat, military necessity, humanity

\section{INTRODUCTION}

It is inconvertible that under international humanitarian law it is unlawful to directly target an enemy who has surrendered. Indeed, surrender is 'one of the most important rules' ${ }^{1}$ of international humanitarian law because it is the '[principal] device for containing destruction and death in our culture of war'. ${ }^{2}$ Without a legal guarantee that they will not be made the object of attack once they have laid down their weapons and submitted themselves to the authority of their enemy, there would be no incentive for those persons engaged in hostilities to surrender and fights to the death would invariably ensue, thereby prolonging armed conflict and fuelling unnecessary violence and suffering. Given the centrality of the rule of surrender to realising the humanitarian objectives of international humanitarian law, it is paramount that those involved in armed conflict are aware of what conduct constitutes an act of surrender under international humanitarian law and thus when its attendant legal obligation to cease fire is triggered. More specifically, questions arise as to the type of conduct that signals an intention to surrender. For example, is the waving of a white flag indicative of surrender? Is retreat tantamount to surrender?

\footnotetext{
* Senior Lecturer in International Law, University of Sheffield, United Kingdom. r.j.buchan@sheffield.ac.uk.

1 'In practice, it [the rule of surrender] is one of the most important rules of the Protocol [Additional Protocol I (n 6 below)]': Yves Sandoz, Christophe Swinarski and Bruno Zimmermann, Commentary to Additional Protocols of 8 June 1977 to the Geneva Conventions of 12 August 1949 (Martinus Nijhoff 1987) 480.

${ }^{2}$ Holger Afflerbach, 'Going Down with Flying Colours: Naval Surrender from Elizabethan to Our Own Times' in Holger Afflerbach and Hew Strachan (eds), How Fighting Ends: A History of Surrender (Oxford University Press 2014) $187,188$.
} 
Another important question is whether combatants are required to offer vanquished forces the opportunity to surrender before direct targeting can commence? Also, must all offers of surrender be accepted or are there circumstances in which an offer of surrender may permissibly be refused?

One would usually expect to find the answers to these questions in those international humanitarian law treaties that contain the rule of surrender. Moreover, one would expect to find the answers to these questions in the military manuals that states produce in order to guide the conduct of their armed forces during times of armed conflict and to streamline their conduct in conformity with international humanitarian law. By and large, however, the treaties do not fully delineate the meaning of the rule of surrender and, while military manuals overwhelmingly require that armed forces do not make surrendered persons the object of attack, they generally fail to specify the conditions that constitute a legally effective surrender.

What is perhaps most surprising is that there has been relatively little consideration of the rule of surrender within international humanitarian law literature. Although this literature routinely identifies the rule of surrender as being part and parcel of modern international humanitarian law and indeed emphasises the importance of this rule within this legal framework, existing literature fails to drill down into this rule and reveal the conditions precedent for an act of surrender to be legally effective. ${ }^{3}$

After uncovering the theoretical basis for the rule of surrender and after identifying relevant state practice in the context of this rule, the objective of this article is to fill this gap in scholarship by clarifying the type of conduct that constitutes an act of surrender under international humanitarian law. Note that the focus of the article is upon the rule of surrender during land warfare in the context of international and non-international armed conflict. This article does not consider when acts of surrender are legally effective during naval and aerial warfare, to which different rules apply. ${ }^{4}$

The article is structured as follows. Section 2 situates surrender within its broader historical and theoretical context in order to provide a better understanding of the development of the rule of surrender within conventional and customary international humanitarian law as well as the function of the rule of surrender during armed conflict. Section 3 explores state practice with a view to identifying when an offer of surrender is effective under international humanitarian law, and proposes a three-stage test that can be used to determine whether an enemy has extended a valid offer of surrender. Section 4 provides some conclusions.

\footnotetext{
${ }^{3}$ The exception here is Horace Robertson, 'The Obligation to Accept Surrender' (1995) 68 International Law Studies 541. However, rather than engaging in an intensive analysis of the rule of surrender during land warfare, Robertson's contribution is a case study that focuses upon whether Iraqi soldiers manning oil platforms during the First Gulf War had effectively expressed an intention to surrender under international humanitarian law before they were attacked by US helicopters.

4 'In the air, it is generally accepted that a crew wishing to indicate their intention to cease combat, should do so by waggling the wings while opening the cockpit': Sandoz, Swinarski and Zimmermann (n 1) 487. 'In naval warfare, the traditional sign of surrender is to strike the flag': Program on Humanitarian Policy and Conflict Research, Commentary on the HPCR Manual on International Law Applicable to Air and Missile Warfare (Cambridge University Press 2010) 266.
} 


\section{The Legal Development of the Rule of Surrender}

The act of surrender possesses a political, military and legal dimension. It has a political dimension in the sense that an act of surrender indicates that a surrendering party has been defeated and the opposing force has been victorious. In its military context the act of surrender denotes that the person surrendering is no longer engaged in hostilities: that he or she is hors de combat. ${ }^{5}$ In its legal dimension, where a valid offer of surrender is communicated to and received by an opposing force, it is legally obligated to accept that offer and refrain from making surrendered persons the object of attack. ${ }^{6}$ This article is concerned with exploring the legal status and content of the rule of surrender and this section traces the emergence of this rule within conventional and customary international humanitarian law during international and non-international armed conflict, as well as identifying its theoretical basis.

\subsection{Customary International Humanitarian Law and the Rule of Surrender}

During prehistoric times tribal societies engaged in almost constant armed conflict. These conflicts were usually fought without mercy because the initiation of armed conflict was regarded as triggering 'total war', a concept that described 'military conflict in which contenders [were] willing to make any sacrifice in lives and other resources to obtain a complete victory'. ${ }^{7}$ Such environments were generally lawless, meaning that the decision to offer surrender was a risky and dangerous option for combatants to take. ${ }^{8}$ Indeed, it was commonplace that combatants who had surrendered were slain or, at a minimum, their lives spared only to be forced into slavery. ${ }^{9}$ As Pictet explains, '[i]n the earliest human societies, what we call the law of the jungle generally prevailed; the triumph of the strongest or most treacherous was followed by monstrous massacres and unspeakable atrocities. The code of honour forbade warriors to surrender; they had to win or die, with no mercy' ${ }^{10}$

\footnotetext{
${ }^{5}$ Hors de combat is a French phrase commonly used in international humanitarian law to mean 'out of combat'.

${ }^{6}$ For the purpose of clarity, it must be stressed that the legal obligation imposed by the rule of surrender is that opposing forces cannot directly target surrendered persons. The rule of surrender does not require the opposing force to detain surrendered persons as prisoners of war (although they can if they wish). Also, although surrendered persons cannot be made the object of attack, they can be the victims of incidental injury as a result of attacks against lawful targets provided that the collateral damage is not excessive in relation to the concrete and direct military advantage anticipated: Protocol Additional to the Geneva Conventions of 12 August 1949, and relating to the Protection of Victims of International Armed Conflicts (entered into force 8 June 1977) 1125 UNTS 3 (Additional Protocol I), art 51(5)(b); Jean-Marie Henckaerts and Louise Doswald-Beck (eds), Customary International Humanitarian Law, Vol I: Rules (International Committee of the Red Cross (ICRC) and Cambridge University Press 2005, reprinted 2009) (ICRC Study) r 14.

7 'Total War', Encyclopedia Britannica Online, 2015, https:/www.britannica.com/topic/total-war.

8 '[T] ribal and pre-state societies seldom [took] prisoners and usually [did] not accept surrender': Lawrence H Keely, 'Surrender and Prisoners in Prehistoric and Tribal Societies' in Afflerbach and Strachan (n 2) 7, 7.

9 'Many bands took no prisoners, not even children or young women. If they did take prisoners it was only young women or some women and children. Any males of fighting age or the elderly that fell into band warriors' power were simply killed. Indeed, I know of no pre-European contact bands that took male adults alive': ibid 8.

${ }^{10}$ Jean Pictet, Development and Principles of International Humanitarian Law (Martinus Nijhoff 1985) 6.
} 
A similar story can be told in relation to the regulation of armed conflict, and thus the regulation of surrender during ancient times. In ancient Greece 'Greek religious beliefs did not give rise to ethical or humanitarian limitations on the conduct of warfare'. ${ }^{11}$ 'Put another way, there were in practice in ancient Greece very few and rather weak constraints upon indulgence in extremes of military anger and hatred, not stopping short of genocide, or at least ethnocide'. ${ }^{12}$ Armed conflict in ancient Greece was therefore largely unregulated and, in particular, 'the Greek code of honor offered no protection to surrendering soldiers'. ${ }^{13}$

The regulation of armed conflict during ancient Rome is captured by Cicero's well-known proverb from $50 \mathrm{BC}$ : silent enim leges inter arma (the law stands silent in times of war). ${ }^{14}$ This rather simplifies the picture because there is evidence that the Romans formulated rudimentary laws of war, such as the prohibition against the use of concealed, barbed and poisoned weapons and the prohibition against attacking religious figures. ${ }^{15}$ This being said, the regulation of armed conflict was skeletal and said very little about how surrendering forces had to be treated. As in ancient Greece, combatants who sought to surrender during armed conflict in ancient Rome were in an extremely precarious position and their fate was entirely at the discretion of the opposing force: the offer of surrender could permissibly be refused and combatants slain. As Polybius put it, '[t]he result was that the Romans enter into possession of everything and those who surrender remain in possession of absolutely nothing'. ${ }^{16}$ This was known as the doctrine of dedito: as soon as opposing forces fell into the hands of the Romans they no longer technically existed and their Roman captors could do with their captives as they pleased. Roman forces did not therefore regard themselves as being subject to a legal obligation to accept offers of surrender. ${ }^{17}$

Heavily influenced by the dictates of Christianity and especially the writings of the leading teachers in the Catholic Church, it was during the Medieval Ages that concerted attempts were made to construct a detailed regulatory framework to govern armed conflict and mitigate the horrors of war. St Augustine's notion of 'just war' implied that resort to war was subject to limitations and that the decision to declare war required justification. ${ }^{18}$ 'Once the idea that warfare might have a legal and theological basis was accepted, it followed naturally that (at least in conflicts between Christian princes) considerations of law and humanity should also influence the conduct of war'. ${ }^{19}$ The emergence of knights and, in particular, the code of chivalry that governed

\footnotetext{
${ }^{11}$ Adriaan Lanni, 'The Laws of War in Ancient Greece' (2008) 26 Law and History Review 469, 476-77.

${ }^{12}$ Paul Cartledge, 'Surrender in Ancient Greece' in Afflerbach and Strachan (n 2) 15, 21. '[T]here is little evidence that the archaic and classical Greeks enacted internationally recognised laws governing the practice of warfare': Josiah Ober, 'Classical Greek Times' in Michael Howard, George J Andreopoulos and Mark R Shulman (eds), The Laws of War: Constraints on Warfare in the Western World (Yale University Press, 1994) 12, 12.

${ }^{13}$ Lanni (n 11) 477.

${ }^{14}$ Virgil, Aeneid, Book 2, 353-54.

${ }^{15}$ See generally Wang Tieya and Wei Min, International Law (Falu Chubanshe 1981) 509-10.

${ }^{16}$ Polybius, The Histories, Vol VI, Book 36 (William Roger Paton tr, Loeb Classical Library 1927).

${ }^{17}$ For a good discussion of surrender in ancient Rome see Loretana de Libero, 'Surrender in Ancient Rome' in Afflerbach and Strachan (n 2) 29.

${ }^{18}$ John Mark Mattox, Saint Augustine and the Theory of Just War (Continuum 2006).

${ }^{19}$ Mary Ellen O'Connell, 'Historical Development and Legal Basis' in Dieter Fleck (ed), The Handbook of International Humanitarian Law (Oxford University Press 2013) 1, para 109.
} 
their interactions had a considerable impact upon the legal regulation of armed conflict. ${ }^{20}$ The kernel of the code of chivalry was that knights were required to treat enemy knights in an honourable and chivalrous manner, and an important principle contained within this code was the obligation to accept valid offers of surrender. ${ }^{21}$ There were, however, three notable exceptions to this rule. First, this code of chivalry applied only to interactions between recognised knights. The code of chivalry did not govern the relations between knights and common warriors; knights, therefore, were not subject to any legal obligation to accept offers of surrender from regular combatants during times of hostilities: "the desperate situation of the common warriors ... must be stressed because it warns us against overstating the so-called "rules of war", which had begun to develop a certain code of human behaviour among noble warriors since the Middle Ages'. ${ }^{22}$ Second, this code of conduct (and so the legal obligation to accept surrender) applied only between knights who were within Christendom: 'the code [of chivalry] was intended to apply only to hostilities between Christian princes and was seldom applied outside that context, for example, in the Crusades'. ${ }^{23}$ Christian knights were therefore relieved of any obligation to accept offers of surrender by non-Christian combatants. ${ }^{24}$ Third, where a city was subject to a siege and the city refused to surrender, once the city was stormed it was accepted that knights were permitted to sack the city and that the normal code of chivalry (and thus the rule mandating the acceptance of surrender) was inoperative. ${ }^{25}$ These exceptions notwithstanding, the rules contained in the code of chivalry 'undoubtedly had a civilizing effect and were a valuable humanitarian development'. ${ }^{26}$ For the first time we witnessed an intellectual appraisal of the conduct of hostilities, the recognition that warfare needed to be subject to limitations, and that these limitations could be achieved through the imposition of legal regulation.

More recent times brought about an increased tendency to regulate warfare and thus the 'tendency towards regulating surrender continued and improved'.${ }^{27}$ In particular, it was the cruelties of the Thirty Years' War that ultimately 'led to the jurisprudential consideration of the jus in bello [the law of war] and established a number of principles to be observed by combatants' ${ }^{28}$

\footnotetext{
${ }^{20}$ See generally Rain Liivoja, 'Chivalry Without a Horse: Military Honour and the Modern Law of Armed Conflict' in Rain Liivoja and Andres Saumets (eds), The Law of Armed Conflict: Historical and Contemporary Perspectives (Tartu University Press 2012) 75.

${ }^{21}$ While there was a clear obligation not to make objects of attack enemy knights who had surrendered, captured knights could still be sold for ransom: John Gillingham, 'Surrender in Medieval Europe - An Indirect Approach' in Afflerbach and Strachan (n 2) 55, 68.

${ }^{22}$ Hans-Henning Kortüm, 'Surrender in Medieval Times' in Afflerbach and Strachan (n 2) 41, 47.

${ }^{23}$ O'Connell (n 19) para 109. See generally Gerald Draper, 'The Interaction of Christianity and Chivalry in the Historical Development of the Law of War' (1965) 5 International Review of the Red Cross 3.

24 'But in wars against outsiders, infidels, or barbarians, the West had inherited a brutal legacy from the Romans which they termed bellum romanum, or guerre mortellle, a conflict in which no holds were barred and all those designated as enemy, whether bearing arms or not, could be indiscriminately slaughtered': Michael Howard, 'Constraints on Warfare' in Howard, Andreopoulos and Shulman (n 12) 1, 3.

${ }^{25}$ Jim Bradbury, The Medieval Siege (The Boydell Press 1998).

${ }^{26}$ O'Connell (n 19) para 109.

${ }^{27}$ Holger Afflerbach and Hew Strachan, “'A True Chameleon”? Some Concluding Remarks on the History of Surrender' in Afflerbach and Strachan (n 2) 435, 442.

${ }^{28}$ O’Connell (n 19) para 113.
} 
An especially important principle that emerged during this period was that of military necessity. According to this principle, combatants could engage only in those measures that were 'indispensable for securing the ends of the war'. ${ }^{29}$ Put otherwise, conduct that was not necessary to hasten the war's end was prohibited.

The principle of military necessity was intended originally therefore to operate as a principle of restraint. However, because military necessity was defined so broadly ('securing the ends of the war') it essentially became a 'doctrine of deference to military judgment about what is really militarily necessary'. ${ }^{30}$ As a result, virtually any conduct could be justified on the basis that it accrued a military advantage, even though it was highly dubious from a humanitarian perspective. Thus, rather than imposing restraint, military necessity acted as a 'permissive' ${ }^{31}$ principle and became 'a license for mischief'. ${ }^{32}$ The principle of military necessity therefore failed to provide an effective mechanism to quell the savagery and brutality associated with previous armed conflicts.

During the Age of Enlightenment and under the tutelage of European philosophers, the principle of humanity emerged as a counterweight to the principle of military necessity. ${ }^{33}$ At the heart of the principle of humanity was the premise that all humans qua humans possessed an inherent human dignity and that 'the law [is] an indispensable instrument for advancing human dignity'. ${ }^{34}$ At first the principle of humanity was used more generally to re-orientate the jurisprudential basis of European societies away from notions of divine right and religious privilege towards the values of equality, tolerance and justice. Eventually, its normative influence impacted upon the regulation of armed conflict and sought to have a humanising effect on it, encouraging the adoption of rules that better protected the human dignity of those embroiled in armed conflict. ${ }^{35}$ The effect was gradually to transform the law of war into an international humanitarian law; thus our modern international humanitarian law - being a corpus of law predicated upon the principles of military necessity and humanity - was born.

On rare occasions the demands of military necessity converge with humanitarian considerations and 'prompt the law in the same direction'. ${ }^{36}$ More often than not, however, the principles

\footnotetext{
${ }^{29}$ Francis Lieber, 'Instructions for the Government of Armies of the United States in the Field', General Order No 100, 24 April 1863 (Lieber Code), art 14.

${ }^{30}$ David Luban, 'Military Necessity and the Culture of Military Law' (2013) 26 Leiden Journal of International Law 315, 343.

31 ibid.

${ }^{32}$ Burrus M Carnahan, 'Lincoln, Lieber and the Laws of War' (1998) 92 American Journal of International Law 213, 217.

33 'A consensus was growing that, although war might still be a necessary element in international politics ... it should be waged, so far as possible, with humanity': Howard (n 24) 6.

${ }^{34}$ Luban (n 30) 316.

${ }^{35}$ See generally Theodor Meron, 'The Humanization of Humanitarian Law' (2000) 94 American Journal of International Law 239. As the International Criminal Tribunal for the Former Yugoslavia (ICTY) would later explain, '[t]he essence of the whole corpus of international humanitarian law as well as human rights law lies in the protection of human dignity in every person ... The general principle of respect for human dignity is ... the very raison d'être of international humanitarian law and human rights law': ICTY, Prosecutor $v$ Furundzija, Judgment, IT-95-17/I-T, Trial Chamber II, 10 December 1998, [183].

${ }^{36}$ Yoram Dinstein, 'Military Necessity', Max Planck Encyclopedia of Public International Law, September 2015, http://opil.ouplaw.com/view/10.1093/law:epil/9780199231690/law-9780199231690-e333.
} 
of military necessity and humanity run into conflict, prompting the law in opposite directions. Where conflict occurs the principles of military necessity and humanity have to be delicately balanced, with rules being produced that reflect a 'dialectical compromise between these two opposing forces'. ${ }^{37}$

The view that surrendered forces should not be made the object of attack is supported by the principles of military necessity and humanity. Where persons clearly indicate that they no longer intend to participate in hostilities, they no longer represent a threat to military security and thus there is no military necessity to target them. ${ }^{38}$ Moreover, to target persons who have placed themselves outside the theatre of war constitutes an unacceptable and indefensible affront to human dignity and is incongruous with the principle of humanity. ${ }^{39}$

Given that the rule of surrender appeals to international humanitarian law's two foundational principles of military necessity and humanity, by the end of the nineteenth century extensive state practice had cohered around the notion that enemy forces who had expressed an intention to surrender must not be made the object of attack. This is significant because where state practice is 'widespread' ${ }^{40}$ within the international society and coupled with opinio juris (the belief that the practice is required by international law), such customary practices give rise to international legal obligations. ${ }^{41}$ Thus, 'by about 1900 , most publicists recognised a customary rule which made it unlawful to refuse quarter or to wound or kill those who unconditionally offered to surrender' ${ }^{42}$

Nowadays, the customary international law status of the rule of surrender is confirmed by the fact that a significant number of military manuals adopted by states - which represent important sources of state practice when identifying obligations under customary international humanitarian $\mathrm{law}^{43}$ - stipulate that it is forbidden to make persons who have surrendered the object of attack. Citing the numerous manuals that impose an obligation upon armed forces to accept valid offers of surrender, Rule 47 of the customary international humanitarian law study by the International

\footnotetext{
${ }^{37}$ Michael N Schmitt, 'Military Necessity and Humanity in International Humanitarian Law: Preserving the Delicate Balance' (2010) 50 Virginia Journal of International Law 795, 798.

${ }^{38}$ As Oeter explains, the obligation to accept valid offers of surrender 'constitutes in essence a logical expression of the principle that the legal use of military violence is strictly limited to what is required by military necessity; clearly there is no necessity to kill persons hors de combat': Stefan Oeter, 'Methods and Means of Combat' in Fleck (n 19) 115, 186-87.

${ }^{39}$ According to the Israeli Military Manual, 'it is absolutely forbidden in the strongest terms to attack such a combatant [one who has surrendered]. The moral argument for this is that as long as the soldier is participating in the military effort, he knowingly risks his life. When he is clearly asking to surrender and exit from the fight or while he is incapable of participating in combat actively, there is no moral justification in attacking him, nor is there any military necessity to do so': Israel, Rules of Warfare on the Battlefield, Military Advocate-General's Corps Command, IDF School of Military Law (2006) 29.

${ }^{40}$ Maritime Delimitation and Territorial Questions between Qatar and Bahrain, Merits [2001] ICJ Rep 40, [205].

${ }^{41}$ As art 38(1)(b) of the Statute of the International Court of Justice explains, customary international law forms on the basis of 'general [state] practice accepted as law': Statute of the International Court of Justice (entered into force 24 October 1945) 1 UNTS XVI, art 38(1)(b).

42 Robertson (n 3) 545.

${ }^{43}$ As the ICTY explained in the Tadic judgment, when identifying state practice in the context of customary international humanitarian law 'reliance must primarily be placed on such elements as official pronouncements of States, military manuals and judicial decisions': ICTY, Prosecutor v Tadic, Decision on the Defence Motion for Interlocutory Appeal on Jurisdiction, IT-94-AR72, Appeals Chamber, 2 October 1995, [99].
} 
Committee of the Red Cross (ICRC) explains that the rule of surrender is a principle of customary international law applicable during international and non-international armed conflict. Rule 47 reads: ${ }^{44}$

Attacking persons who are recognized as hors de combat is prohibited. A person hors de combat is:

(a) anyone who is in the power of an adverse party;

(b) anyone who is defenceless because of unconsciousness, shipwreck, wounds or sickness; or

(c) anyone who clearly expresses an intention to surrender;

provided he or she abstains from any hostile act and does not attempt to escape.

\subsection{Treaty Law and the Codification of the Rule of Surrender}

During the American Civil War the US government charged the renowned American-German jurist Francis Lieber to draft a document which contained the basic principles and accepted rules of war on land to regulate the conduct of the Union's military forces during its armed conflict with the Confederate army. The Lieber Code (as it became known) was promulgated by US President Abraham Lincoln to Union forces in 1863 and represented the first attempt to codify and systematise the law of war generally and the rule relating to surrender in particular. Article 60 of the Lieber Code explained that it was unlawful for Union forces to 'refuse quarter', which was interpreted to mean that Union forces were legally prohibited from making the object of attack members of the Confederate army who had surrendered.

The Lieber Code is often regarded as providing the foundation for subsequent attempts to regulate warfare. The Brussels Manual of 1874, although never attaining the status of treaty law, also precluded the refusal of quarter. ${ }^{45}$ The Oxford Manual of 1880, a non-binding document produced by the Institute of International Law, explained that it was prohibited to 'injure or kill an enemy who has surrendered at discretion or is disabled, and to declare in advance that quarter will not be given, even by those who do not ask it for themselves'. ${ }^{46}$ Undoubtedly, the Brussels and Oxford Manuals heavily influenced the trajectory of the Hague Peace Conferences in 1899 and 1907 and the Regulations that these conferences produced. Article 23 of both the Hague Conventions II (1899) $)^{47}$ and IV (1907) $)^{48}$ provides:

\footnotetext{
${ }^{44}$ ICRC Study (n 6) r 47. The ICRC Study is not a source of international law but instead intends to capture and delineate customary rules of international humanitarian law applicable to international and non-international armed conflict: ibid xxiv.

${ }^{45}$ Project of an International Declaration concerning the Laws and Customs of War 1874, adopted by the Conference of Brussels, 27 August 1874 (the Brussels Manual), art 13(d).

${ }^{46}$ The Laws of War on Land, 9 September 1880 (the Oxford Manual), art 9(b).

${ }^{47}$ Hague Convention (II) with respect to the Laws and Customs of War on Land and its Annex: Regulations concerning the Laws and Customs of War on Land (entered into force 4 September 1900) 26 Martens Nouveau Recueil (ser 2) 949.

${ }^{48}$ Hague Convention (IV) respecting the Laws and Customs of War on Land and its Annex: Regulations concerning the Laws and Customs of War on Land (entered into force 26 January 1910) Martens Nouveau Recueil (ser 3 ) 461 .
} 
It is especially forbidden ...

c) To kill or wound an enemy who, having laid down his arms, or having no longer means of defence, has surrendered at discretion

d) To declare that no quarter will be given.

Both Additional Protocols to the 1949 Geneva Conventions ${ }^{49}$ impose an obligation upon state parties to refrain from making the object of attack a person who has expressed an intention to surrender. In the context of an international armed conflict, Article 40 of Additional Protocol I explains that 'it is prohibited to order that there shall be no survivors'. Article 41(1) further explains that a person 'hors de combat shall not be made the object of attack'; Article 41(2) explains that a person is hors de combat if 'he clearly expresses an intention to surrender'.

With regard to non-international armed conflict, Article 4 of Additional Protocol II delineates a number of 'fundamental guarantees' and specifically states:

All persons who do not take a direct part or who have ceased to take part in hostilities, whether or not their liberty has been restricted, are entitled to respect for their person, honor and convictions and religious practices. They shall in all circumstances be treated humanely, without any adverse distinction. It is prohibited to order that there shall be no survivors.

This has been consistently interpreted as imposing a treaty obligation upon parties to this Protocol to accept valid offers of surrender. ${ }^{50}$

Furthermore, the Rome Statute establishing the International Criminal Court (ICC Statute) determines that in times of international ${ }^{51}$ and non-international armed conflict $^{52}$ it is a war crime to make the object of attack persons who have surrendered.

\section{When is SurRender EfFective Under InTERnAtional Humanitarian LaW?}

Now that the theoretical basis for the rule of surrender has been revealed, it can be utilised as a lens through which state practice relating to surrender can be observed and scrutinised. In turn,

\footnotetext{
${ }^{49}$ Additional Protocol I (n 6); Protocol Additional to the Geneva Conventions of 12 August 1949, and relating to the Protection of Victims of Non-International Armed Conflicts (entered into force 7 December 1978) 1125 UNTS 609 (Additional Protocol II).

${ }^{50}$ Robertson (n 3) 547. Additionally, the ICRC Study determined that the content of art 4 is contained (albeit implicitly) in Common Article 3 to the Four Geneva Conventions of 1949, which can be regarded, therefore, as imposing a legal obligation upon state parties to refrain from making the object of attack persons who have surrendered during a non-international armed conflict: ICRC Study (n 6) 165, r 47 and accompanying commentary. See Geneva Convention (I) for the Amelioration of the Condition of the Wounded and Sick in Armed Forces in the Field (entered into force 21 October 1950) 75 UNTS 31, art 3; Geneva Convention (II) for the Amelioration of the Condition of Wounded, Sick and Shipwrecked Members of Armed Forces at Sea (entered into force 21 October 1950) 75 UNTS 85, art 3; Geneva Convention (III) relative to the Treatment of Prisoners of War (entered into force 21 October 1950) 75 UNTS 135 (GC III), art 3; GC IV (n 6) art 3 (Common Article 3).

${ }^{51}$ Rome Statute establishing the International Criminal Court (entered into force 3 September 2002) 2187 UNTS 90 (ICC Statute), art 8(2)(b)(vi).

52 ibid art $8(2)(\mathrm{e})(\mathrm{x})$.
} 
this will allow for the conditions that trigger the obligation to accept offers of surrender under international humanitarian law to be more easily discerned and better understood.

Military manuals - which, as I have already explained, represent important sources of state practice that can be used to interpret treaty rules and obligations under customary international humanitarian law - generally fail to address how surrender can be achieved in practical terms during land warfare. Moreover, there are few reported instances of surrender occurring during actual hostilities that have raised difficulties under international humanitarian law, meaning that by and large states have not been formally required to determine the content and scope of the rule of surrender. Such limited state practice, of course, creates difficulties in attempting to define the contours of a rule of treaty and customary law. Nevertheless, available state practice, in conjunction with the wider theoretical context within which the rule of surrender operates, can be used to make general inferences and to draw tentative conclusions as to the meaning of this rule under international humanitarian law. Accordingly, I propose a three-stage test for determining when an act of surrender is legally effective under international humanitarian law:

1. Have persons who are attempting to surrender engaged in a positive act which clearly indicates that they no longer intend to directly participate in hostilities?

2. Is it reasonable in the circumstances for the opposing force to discern the offer of surrender? and

3. Have persons who are surrendering unconditionally submitted to the authority of their captor?

These three limbs will be now explored in greater detail.

\subsection{A Positive Act Indicating an Intention to No Longer Directly Participate in HostiLitIES}

If the rationale underlying the rule of surrender is that there is no military necessity to attack persons who have expressed the intention to no longer directly participate in hostilities, then it follows that it is only those persons who directly participate in hostilities who possess the legal capacity to surrender under international humanitarian law. If this is the case, it becomes clear that in order to surrender it is incumbent upon such persons to perform a 'positive act', ${ }^{53}$ which indicates 'in an absolutely clear manner' 54 that they no longer intend to directly participate in hostilities and therefore no longer represent a threat to the military security of the opposing party.

Before we examine what type of conduct constitutes a positive act indicating an intention to no longer directly participate in hostilities, it is first necessary to identify those persons whom international humanitarian law regards as directly participating in hostilities during armed conflict, because it is within this context that the rule of surrender operates.

\footnotetext{
${ }^{53}$ Hilaire McCoubrey and Nigel D White, International Humanitarian Law: The Regulation of Armed Conflict (Dartmouth 1992) 227.

${ }^{54}$ Sandoz, Swinarski and Zimmermann (n 1) 487.
} 
Broadly speaking, the law of international armed conflict distinguishes between two categories of people: combatants and civilians. Combatants are assumed to be constantly directly participating in hostilities and are incontrovertibly permissible objects of attack. ${ }^{55}$ Combatants include those persons who are incorporated into the regular armed forces of a state by domestic law. Combatants also include those members of irregular armed forces (such as militias and volunteer corps $)^{56}$ - being groups who exhibit 'a sufficient degree of military organization and belong to a party to the conflict' ${ }^{57}$ - who possess a 'continuous combat function' ${ }^{58}$ Continuous combat function requires lasting integration into the irregular group, which encompasses those individuals 'who have directly participated in hostilities on repeated occasions in support of an organized armed group in circumstances indicating that their conduct reflects a continuous combat role rather than a spontaneous or sporadic or temporary role assumed for the duration of a particular operation'. 59

Combatants who wish to surrender must act purposively in order to repudiate the assumption that they represent a threat to military security. In the words of the United States Law of War Deskbook (which is distributed as part of the Judge Advocate Officer Graduate and Basic Courses), "the burden is upon the surrendering party to make his intentions clear, unambiguous, and unequivocal to the capturing unit'. ${ }^{60}$

The law of international armed conflict defines civilians in negative terms as those persons who do not qualify as combatants. ${ }^{61}$ As civilians do not directly participate in hostilities they do not pose a threat to the military security of the opposing party. For this reason it is a 'cardinal principle' and 'intransgressible rule' of international humanitarian law that civilians cannot be

\footnotetext{
${ }^{55}$ Additional Protocol I (n 6) art 50(1); ICRC Study (n 6) r 6. '[I]t is always permissible due to military necessity to attack the enemy's combatants. This is so because an individual soldier will always be adding to the military capacity of the enemy': Ian Henderson, The Contemporary Law of Targeting (Martinus Nijhoff 2009) 86-87.

${ }^{56} \mathrm{GC}$ III (n 50) art 4A. Although formally the purpose of art 4A is to delineate the criteria for determining who can be regarded as prisoners of war under the law of international armed conflict, it has become well accepted that this provision also provides the criteria for determining lawful combatancy during international armed conflict: Yoram Dinstein, The Conduct of Hostilities under the Law of International Armed Conflict (Cambridge University Press 2016) 49-51.

${ }^{57}$ Nils Melzer, Interpretive Guidance on the Notion of Direct Participation in Hostilities under International Humanitarian Law (ICRC 2009) 22.

${ }^{58}$ That it is only those members of an organised armed group possessing a continuous combat function to directly participate in hostilities who are to be regarded as combatants derives from the ICRC's Interpretive Guidance, ibid 25. Other commentators disagree with the ICRC's approach and argue that all 'members of the military component may be treated as members of an organized armed group for targeting purposes' regardless of the function they perform: Michael N Schmitt and Eric W Widmar, "'On Target”: Precision and Balance in the Contemporary Law of Targeting' (2014) 7 Journal of National Security and Policy 379, 387. Although not a source of law, since its publication the Interpretive Guidance has gained 'traction' among states and is thus 'becoming the authoritative guidance' on the law of targeting: Jeremy Marsh and Scott L Glebe, 'Time for the United States to Directly Participate' (2011) 1 Virginia Journal of International Law Online 1, 20.

${ }^{59}$ UN General Assembly, Report of the Special Rapporteur on the Promotion and Protection of Human Rights and Fundamental Freedoms while Countering Terrorism (18 September 2013), UN Doc A/68/389, para 69.

${ }^{60}$ US Law of Armed Conflict Deskbook (International and Operational Department 2015) 78.

61 '[A]11 persons who are neither members of the armed forces of a party to the conflict nor participants in a levée en masse are civilians': Additional Protocol I (n 6) art 50(1).
} 
directly targeted. ${ }^{62}$ Given their legal immunity from direct targeting, civilians do not have the legal capacity to surrender.

In those instances where civilians do 'directly participate in hostilities' they emerge as a threat to the opposing force and thus the notion of military necessity justifies their direct targeting. ${ }^{63}$ Conduct amounting to direct participation in hostilities includes 'acts of war which by their nature or purpose are likely to cause actual harm to the personnel or materiel of the enemy armed forces' ${ }^{64}$ Civilians are liable to direct targeting 'for such time' ${ }^{65}$ as they directly participate in hostilities, and this includes the period during which the civilian is preparing to engage in conduct amounting to direct participation, actually engages in hostilities, and in the immediate aftermath of the hostile act being perpetrated. ${ }^{66}$ During the period of direct participation civilians are able to surrender and, as with combatants, in order to do so they must perform a positive act which clearly indicates that they no longer intend to directly participate in hostilities.

The conventional view is that where civilians repeatedly directly participate in hostilities they retain their immunity from direct targeting even during intermissions in direct participation. ${ }^{67}$ Certain states maintain the view that where civilians repeatedly participate directly in hostilities to the extent that their future participation is likely and predictable, they remain a threat to the military security of the opposing party and can be directly targeted even notwithstanding lulls in participation. ${ }^{68}$ Although this is a controversial interpretation of international humanitarian law, ${ }^{69}$ if we accept arguendo that this view represents lex lata (the law as it stands) civilians who repeatedly directly participate in hostilities possess the capacity to surrender and, in order to become hors de combat and enjoy immunity from direct targeting, they must perform a positive act which signals that they no longer intend to participate in hostilities.

With regard to the law applicable during non-international armed conflict, combatancy status does not exist because states are loathe to confer on insurgents the combatancy privilege that is available in international armed conflict - namely, immunity from prosecution under national law. ${ }^{70}$ Instead, states regard insurgents as criminals and terrorists who must be held criminally

\footnotetext{
${ }^{62}$ Legality of the Threat or Use of Nuclear Weapons, Advisory Opinion [1996] ICJ Rep 226, paras 78, 79.

${ }^{63}$ That civilians can be directly targeted in international armed conflicts where they directly participate in hostilities is expressly mentioned in art 51(3) Additional Protocol I (n 6) and is undoubtedly representative of customary international humanitarian law: HCJ 769/02 Public Committee Against Torture in Israel and Palestinian Society for the Protection of Human Rights and the Environment v Israel and Others ILDC 597 (IL 2006) [2006], para 35. ${ }^{64}$ ICTY, Prosecutor v Galić, Judgment, IT-98-29-T, Trial Chamber, 5 December 2003, [48]. The ICRC's Interpretive Guidance provides a fuller discussion of when a person can be regarded as directly participating in hostilities: Melzer (n 57) 41-64.

${ }^{65}$ Additional Protocol I (n 6) art 51(3).

${ }^{66}$ Melzer (n 57) 65-68.

67 ibid 70 .

68 'The law of war, as applied by the United States, gives no "revolving door" protection; that is, the off-and-on protection in a case where a civilian repeatedly forfeits and regains his or her protection from being made the object of attack depending on whether or not the person is taking a direct part in hostilities at that exact time': US Department of Defense, Law of War Manual (2015, updated 2016) para 5.8.4.2.

${ }^{69}$ The ICRC, for example, expressly considers and then rejects this contention: Melzer (n 57) 70.

${ }^{70}$ Louise Doswald-Beck, 'The Right to Life in Armed Conflict: Does International Humanitarian Law Provide All the Answers?' (2006) 88 International Review of the Red Cross 881, 889.
} 
responsible for their violent and seditious conduct. For the purpose of targeting, and in order to maintain the principle of distinction during non-international armed conflict, the law of such conflict distinguishes between, on the one hand, 'armed forces' and 'armed groups' (who are often referred to collectively as 'fighters' ${ }^{71}$ ) and, on the other hand, 'civilians'. ${ }^{72}$ 'Fighters' include those persons who are formally incorporated into a state's armed forces via domestic law and those members of an organised armed group who belong to a state that is party to the armed conflict and who possess a continuous combat function. ${ }^{73}$ The notion of fighters also includes those members of an organised armed group that is party to a non-international armed conflict and who possess a continuous combat function. ${ }^{74}$ Fighters are assumed to be continually participating directly in hostilities (even during lulls in participation) and the demands of military necessity justify their direct targeting. Yet, the threat they represent can be repudiated, and thus immunity from direct targeting acquired, where they perform a positive act indicating they no longer intend to participate in hostilities - that is, they surrender.

Unlike international armed conflicts, the law of non-international armed conflict does not expressly define the concept of civilian notwithstanding the fact that treaty law applicable to noninternational armed conflict uses the term 'civilian' on a number of occasions. ${ }^{75}$ However, the phraseology of these agreements means that civilians necessarily fall into a residual category of anyone who is not a fighter. Civilians enjoy protection from direct targeting under international humanitarian law but can be made the object of attack during such time as they directly participate in hostilities. ${ }^{76}$ Where they directly participate in hostilities they have the legal capacity to surrender and, in order to do so, they must engage in a positive act that clearly demonstrates their intention that they no longer wish to participate in hostilities.

That the onus is upon those wishing to surrender to indicate unambiguously that they no longer intend to take a direct part in hostilities explains why international humanitarian law does not impose an obligation upon an opposing force to first offer its enemy the opportunity to surrender before making them the object of an attack, ${ }^{77}$ regardless of how hopelessly outgunned and vanquished they may be. ${ }^{78}$

\footnotetext{
${ }^{71}$ Marco Sassòli and Laura M Olson, 'The Relationship between International Humanitarian and Human Rights Law Where It Matters: Admissible Killing and Internment of Fighters in Non-International Armed Conflicts' (2008) 90 International Review of the Red Cross 599, 606.

${ }^{72}$ Common Article 3 (n 50); Additional Protocol II (n 49) art 1.

${ }^{73}$ Melzer (n 57) 31.

${ }^{74}$ ibid 34 .

${ }^{75}$ For example, the concept of civilian is used in Additional Protocol II (n 49) arts 13 and 17.

${ }^{76}$ ibid art 13(3).

77 'A combatant force involved in an armed conflict is not obligated to offer its opponent an opportunity to surrender before carrying out an attack': US Department of Defense, 'Report to Congress on the Conduct of the Persian Gulf War - Appendix on the Role of the Law of War' (1992) 31 ILM 612, 641.

${ }^{78}$ This being said, under international humanitarian law persons are regarded as hors de combat and thus immune from attack where they are 'in the power of the adverse party': Additional Protocol I (n 6) art 41(2)(a); ICRC Study (n 6) $r$ 47. In order to be in the power of an adverse party the person in question does not have to be physically apprehended by the opposing force. Even in the absence of physical apprehension a person can be so utterly in the power of the opposing force that he or she can no longer be regarded as representing a military threat. In such instances the adverse party is not under an obligation to offer its opponent the opportunity to surrender before
} 
International human rights law may muddy the waters here. International tribunals have determined that during times of international and non-international armed conflict international humanitarian law does not displace the obligations imposed upon states by international human rights law. ${ }^{79}$ Yet, the circumstances in which international human rights law is operative during international and non-international armed conflict is far from clear and this is particularly so in relation to the law of targeting. ${ }^{80}$ If international human rights law were to govern the manner in which a party to an armed conflict targets its enemy this would have a profound impact upon whether and to what extent force can be used permissibly. In short, while international humanitarian law permits parties to an armed conflict to attack (and kill) enemies, even where they are not engaging in threatening behaviour (and assuming they are not hors de combat), international human rights law permits a state to use force only where it is necessary and proportionate in the circumstances prevailing at the time. ${ }^{81}$ Depending upon the circumstances, in the majority of instances it is likely that in order for force to be deemed necessary, the state must first utilise all reasonable measures at its disposal to communicate to the enemy an offer of surrender and, subsequently, to ascertain whether that offer has been accepted or rejected. ${ }^{82}$

In the Nuclear Weapons advisory opinion the ICJ opined that during times of armed conflict (presumably encompassing both international and non-international armed conflict) the legality of the use of lethal force must be determined according to the applicable lex specialis - meaning that the law governing a specific subject matter takes precedence over law that regulates general

direct targeting can commence but, instead, international humanitarian law prohibits the adverse party from making such a person the object of attack.

79 'More generally, the Court considers that the protection offered by human rights conventions does not cease in case of armed conflict': Legal Consequences of the Construction of a Wall in the Occupied Palestinian Territory, Advisory Opinion [2004] ICJ Rep 136, [106]. In the Armed Activities case the ICJ held that 'both branches of international law, namely international human rights law and international humanitarian law, would have to be taken into consideration': Case concerning Armed Activities on the Territory of the Congo (Democratic Republic of Congo v Uganda), Judgment [2005] ICJ Rep 168, [216].

${ }^{80}$ As Lubell explains, '[w]hen we actually come to apply human rights law in practice to situations of armed conflict, certain difficulties do appear': Noam Lubell, 'Challenges in Applying Human Rights Law to Armed Conflict' (2005) 87 International Review of the Red Cross 737, 738.

${ }^{81}$ See, eg, ECtHR, McCann v United Kingdom, App no 18984/91, Judgment, 5 September 1995, paras $200-205$.

${ }^{82}$ For example, the Human Rights Committee determined that Colombia had failed to comply with its international human rights law obligations when using force against members of an organised armed group because Colombian forces did not offer their opponents the opportunity to surrender before targeting (and killing) them. In the words of the Committee, 'the police action was apparently taken without warning to the victims and without giving them any opportunity to surrender to the police patrol or to offer any explanation of their presence or intentions': Human Rights Committee, Suarez de Guerrero v Colombia, Communication No. R.11/45, 31 March 1982, UN Doc Supp No 40 (A37/40), para 13.2. See also Basic Principles on the Use of Force and Firearms by Law Enforcement Officials, adopted by the 9th UN Congress on the Prevention of Crime and Treatment of Offenders, Havana, 27 August-7 September 1990, UN Doc A/CONF.144/28/Rev.1 (1990), art 10 of which provides that before using force, law enforcement officials 'shall ... give a clear warning of their intent to use firearms, with sufficient time for the warning to be observed, unless to do so would unduly place the law enforcement officials at risk or would create a risk of death or serious harm to other persons'. 
matters where there is inconsistency between them ${ }^{83}$ - which, in the context of armed conflict, would be international humanitarian law. In the Court's often quoted dictum: ${ }^{84}$

In principle, the right not arbitrarily to be deprived of one's life applies also in hostilities. The test of what is an arbitrary deprivation of life, however, then falls to be determined by the applicable lex specialis, namely, the law applicable in armed conflict which is designed to regulate the conduct of hostilities.

During times of international armed conflict state practice is 'fairly uniform' ${ }^{85}$ and reveals that targeting is to be conducted according to the more permissive standards set by international humanitarian law rather than the more restrictive standards imposed by international human rights law. ${ }^{86}$

In the context of non-international armed conflict international tribunals have at times concurred with the ICJ in the Nuclear Weapons advisory opinion and concluded that the legality of the use of force by states must be determined according to international humanitarian law criteria ${ }^{87}$ In other instances, however, international tribunals and human rights bodies have deviated from Nuclear Weapons and applied human rights law standards in determining the legality of the use of force by states. ${ }^{88}$ As Sassòli and Olson explain, case law in this area is 'clearly contradictory ${ }^{89}$ and 'gives no conclusive answer as to what human rights law requires of government authorities using force against fighters'. ${ }^{90}$

In normative terms, commentators have increasingly argued that 'whenever a state has enough control over a particular situation to enable it to detain individuals, then such an attempt must be made before force can be used, and non-lethal force must be favoured if possible'. ${ }^{11}$ The view is

\footnotetext{
83 'For the lex specialis principle to apply it is not enough that the same subject matter is dealt with by two provisions; there must be some actual inconsistency between them, or else a discernible intention that one provision is to exclude the other': International Law Association, Draft Articles on Responsibility of States for Internationally Wrongful Acts, with Commentaries (2001) Yearbook of the International Law Commission, Vol II, Pt Two, 140. ${ }^{84}$ Nuclear Weapons (n 62) [25].

${ }^{85}$ Sassòli and Olson (n 71) 603.

86 'For combatants in international armed conflicts, international humanitarian law is generally considered to constitute the lex specialis in relation to the amount of force to be used against enemy combatants': UN Human Rights, Office of the High Commissioner, International Legal Protection of Human Rights in Armed Conflict (United Nations 2011) 67. "As such, the "active hostilities" framework [i.e. international humanitarian law] regulates the use of force against all combatants, military objectives, members of an armed group belonging to a party to the [international armed] conflict, and individuals directly participating in hostilities, irrespective of their location to any active battlefield': Daragh Murray and others, Practitioners' Guide to Human Rights Law in Armed Conflict (Oxford University Press 2016) para 5.06.

${ }^{87}$ Case of Abella v Argentina (Tabala) (1997) Inter-Am Ct HR, Case No 11.137, Report No 55/97, 18 November 1997.

${ }^{88}$ See, eg, Human Rights Committee, Suarez de Guerrero (n 82). For a more detailed discussion of decisions of UN human rights bodies that have applied international human rights law in determining the legality of the use of force by states during non-international armed conflicts see Sassòli and Olson (n 71) 611-12.

${ }^{89}$ Sassòli and Olson, ibid 603.

90 ibid 612 .

${ }^{91}$ Lubell (n 80) 750. The question then becomes what degree of control over the situation is needed in order to invoke the application of international human rights law. The general view is that where '[a] government could
} 
that where a state and an organised armed group are actually engaging in armed hostilities, this is precisely the scenario where humanitarian law is designed to apply. Where, however, a confrontation occurs between a state and an armed group within that state's territory, and that state exercises control over the situation, the members of the armed group are under the jurisdiction of the state and this is a scenario that typically 'points to human rights as the lex specialis' ${ }^{92}$

As the law of non-international armed conflict in the context of targeting is currently 'unclear', ${ }^{93}$ it is difficult to draw firm conclusions. If the approach described above gains traction within state practice (as it has done within academic literature), ${ }^{94}$ the consequence would be that where a situation is under the control of a state ${ }^{95}$ that is party to a non-international armed conflict, targeting decisions must be guided by the standards set by international human rights law, which means that states must make all reasonable efforts to communicate to their enemies the offer of surrender before they can be directly targeted.

There is one instance where a party to an armed conflict is legally required to offer opposing forces the opportunity to surrender before direct targeting can commence. Article 42 of Additional Protocol I provides that in an international armed conflict 'no person parachuting from an aircraft in distress shall be made the object of attack during his descent' and, upon reaching enemy territory, he or she must be given a 'reasonable opportunity to surrender before being made the object of attack, unless it is apparent that he is engaging in a hostile act'. Although Article 42 relates to international armed conflicts, the rule it contains applies also to noninternational armed conflicts on the basis of Common Article 3 of the four Geneva Conventions, which protects persons placed hors de combat by 'any' cause. In addition, Rule 48 of the ICRC Study explains that in times of international and non-international armed conflict, customary international law prohibits making persons parachuting from an aircraft in distress the object of attack. ${ }^{96}$

The rationale underlying this rule can be explained on the basis that where it is discernible that persons have parachuted from an aircraft in distress and are not engaging in hostile acts, this is regarded as a form of positive conduct that signals that they no longer represent a threat to military security and thus there is no military necessity to directly target them. However, where persons parachute from an aircraft and are not in distress, or are in distress but nevertheless engage in a hostile act, a threat to military security is present and they may be made the object of attack. Indeed, it is for this reason that Article 42 of Additional Protocol I expressly provides

\footnotetext{
effect arrest (of individuals or groups) without being overly concerned about interference by other rebels on that operation, then it has sufficient control over the place to make human rights prevail as lex specialis': Sassòli and Olson (n 71) 614.

${ }^{92}$ Sassòli and Olson (n 71) 614.

${ }^{93}$ ibid 606.

${ }^{94}$ See, eg, Doswald-Beck (n 70), Lubell (n 80), Sassòli and Olson (n 71), Murray and others (n 86) para 511.

${ }^{95}$ The general view is that international human rights law only imposes obligations upon states. The upshot of this is that non-state actors such as organised armed groups that are party to a non-international armed conflict cannot be the bearer of obligations under international human rights law: Philip Alston, 'The "Not-a-Cat" Syndrome: Can the International Human Rights Regime Accommodate Non-State Actors?' in Philip Alston (ed), Non-State Actors and Human Rights (Oxford University Press 2005) 3.

${ }^{96}$ ICRC Study (n 6) r 48.
} 
that 'airborne troops are not protected' by this rule - airborne troops are militarily active and have yet to engage in a positive act that indicates an intention to place themselves hors de combat. Put differently, there is a pressing military need to target them directly.

Moving forward, the next question that needs to be addressed is the nature of the positive act that persons must exhibit in order to reveal an intention that they no longer intend to directly participate in hostilities. Article 23(c) of Hague Convention IV ${ }^{97}$ explains that it is prohibited ' $[\mathrm{t}] \mathrm{o}$ kill or wound an enemy who, having laid down his arms, or having no longer means of defence, has surrendered at discretion'. The wording of this provision is repeated verbatim in Article $8(2)$ (b)(vi) of the ICC Statute, ${ }^{98}$ which stipulates that in times of an international armed conflict it is a war crime to kill or wound a person who, 'having laid down his arms or having no means of defence, has surrendered at discretion'. At least for the purpose of these international legal rules, the laying down of weapons is an effective method through which to express an intention to surrender.

While other international humanitarian law treaties impose an obligation upon opposing forces to accept valid offers of surrender, they do not provide any guidance as to the type of conduct (verbal or otherwise) that signifies an intention to surrender. For example, Article 41(2) of Additional Protocol I expressly imposes an obligation to accept offers of surrender but merely states that a person is hors de combat where he or she 'expresses an intention to surrender'. Similarly, although containing the rule of surrender, Common Article 3 and Article 4 of Additional Protocol II do not specify the conditions that constitute an effective surrender. The ICRC insists that customary international law also imposes an obligation to refrain from targeting those who have surrendered, yet Rule 47 of the ICRC Study provides no further guidance on what conduct constitutes a legally effective surrender, stating merely that a person is immune from attack where he or she 'expresses an intention to surrender'.

Guidance on how a person expresses an intention to surrender is provided by the Official Commentary to Article 41(2) of Additional Protocol I: ${ }^{99}$

In land warfare ... a soldier who wishes to indicate that he is no longer capable of engaging in combat, or that he intends to cease combat, lays down his arms and raises his hands. Another way is to ceasefire, wave a white flag and emerge from a shelter with hands raised ... If he is surprised, a combatant can raise his arms to indicate that he is surrendering, even though he may still be carrying weapons.

This chimes with the ICRC commentary to Rule 47 which, after citing 'many military manuals', explains that '[i]n land warfare, a clear intention to surrender is generally shown by laying down one's weapons and raising one's hands' or by 'displaying a white flag'. ${ }^{100}$

\footnotetext{
${ }^{97} \mathrm{n} 48$.

$98 \mathrm{n} 51$.

${ }^{99}$ Sandoz, Swinarski and Zimmermann (n 1) 486-87.

${ }^{100}$ ICRC Study (n 6) 168. A number of academics also hold this view: eg, Sandesh Sivakumaran, The Law of Non-International Armed Conflict (Oxford University Press 2012) 413 (an intention to surrender is indicated in 'the form of waving a white flag or discarding weapons and placing hands on heads').
} 
Given that the relevant treaties are silent as to the conduct that constitutes an act of surrender, state practice becomes an important indicator of the ways in which ambiguous or unclear treaty provisions must be interpreted. ${ }^{101}$ State practice (coupled with opinio juris) is also key to interpreting obligations imposed by customary international law. ${ }^{102}$ In essence, then, whether the discarding of weapons (where a person is in possession of weapons) and placing hands above the head or waving a white flag constitute an effective method of expressing an intention to surrender boils down to whether such conduct is supported by state practice.

Importantly, a significant number of military manuals produced by states identify the laying down of weapons and the raising of hands as an acceptable means through which to manifest an intention to surrender, ${ }^{103}$ indicating that such conduct achieves sufficient support among states to amount to a legally recognisable act of surrender under relevant treaty and customary international humanitarian law. The picture is more complex in relation to the white flag.

In lay terms many are likely to regard the waving of the white flag as a widely recognised method of indicating a desire to surrender. Indeed, there is support for this approach in a number of military manuals. For example, Cameroon's Instructor's Manual explains that 'the white flag is the symbol of surrender of troops and engages the adversary to respect immediately the ceasefire rules'. ${ }^{104}$ Belgium's Teaching Manual for Soldiers also supports this approach, stating that 'the intention to surrender may be expressed in different ways: laying down arms, raised hands, white flag'. ${ }^{105}$ France's Manual on the Law of Armed Conflict explains that '[a]n intention to surrender must be clearly expressed; by raising hands, throwing down weapons or waving a white flag'. ${ }^{106}$ Similarly, the Dominican Republic's Military Manual accepts that once a white flag is waved this signals an intent to surrender and the opposing force must cease firing from that moment: 'The enemy soldier may reach a point where he would rather surrender than fight. He may signal to you with a white flag, by emerging from his position with arms raised or yelling to ceasefire'. ${ }^{107}$

However, not all states identify the white flag as being indicative of an intention to surrender. In fact, a number of states expressly reject the contention that the waving of a white flag is constitutive of surrender. The United States, for example, claims that ' $[w]$ aving a white flag

\footnotetext{
${ }^{101}$ Vienna Convention on the Law of Treaties (entered into force 28 January 1980) 1155 UNTS 331, art 31(3)(b).

${ }^{102}$ Statute of the International Court of Justice (n 41) art 38(1)(b).

${ }^{103}$ US Law of War Manual (n 68) para 5.9.3.2.; France, Manuel de Droit des Conflits Armés, Ministère de la Défense, Direction des Affaires Juridiques, Sous-Direction du droit international humanitaire et du droit européen, Bureau du droit des conflits armés (2001) 105; Belgium, Droit de la Guerre, Dossier d'Instruction pour Soldat, à l'attention des officiers instructeurs, JS3, Etat-Major Général, Forces Armées belges, undated, 15; Cameroon, Droit des conflits armés et droit international humanitaire, Manuel de l'instructeur en vigueur dans les forces de défense, Présidence de la République, Ministère de la Défense, Etat-major des Armées (2006) 256; Benin, Le Droit de la Guerre, III fascicules, Forces Armées du Bénin, Ministère de la Défense nationale (1995); Chad, Droit international humanitaire, Manuel de l'instructeur en vigueur dans les forces armées et de sécurité, Ministère de la Défense, Présidence de la République, Etat-major des Armées (2006).

${ }^{104}$ Cameroon, ibid.

${ }^{105}$ Belgium (n 103).

${ }^{106}$ France (n 103).

${ }^{107}$ Dominican Republic, La Conducta en Combate según las Leyes de la Guerra, Escuela Superior de las FF.AA. 'General de Brigada Pablo Duarte', Secretaría de Estado de las Fuerzas Armadas (1980) 6-7.
} 
technically is not a sign of surrender, but signals a desire to negotiate'108 and that ' $[\mathrm{t}]$ he hoisting of a white flag has no other legal meaning in the law of war'. ${ }^{109}$ The US Law of Armed Conflict Deskbook also rejects the use of the white flag as being declarative of surrender, and discusses the use of the white flag in the context of the 1982 Falklands Conflict: ${ }^{110}$

During the Battle for Goose Green, some Argentinean soldiers raised a white flag. A British lieutenant and two soldiers advanced to accept what they thought was a proffered surrender. They were killed by enemy fire in a disputed incident. Apparently, one group of Argentines was attempting to surrender, but not the other group. The Argentine conduct was arguably treachery if those raising the white flag killed the British soldiers, but not if other Argentines fired unaware of the white flag. This incident emphasizes the rule that the white flag indicates merely a desire to negotiate, and its hoister has the burden to come forward.

Other states similarly reject the contention that the white flag indicates an intention to surrender. For example, Canada's Code of Conduct states that ' $[\mathrm{t}]$ he showing of a white flag is not necessarily an expression of an intent to surrender'. ${ }^{111}$ The Teaching Manual for the armed forces of Côte d'Ivoire also explains that ' $[\mathrm{t}]$ he white flag is used to indicate the intention to negotiate and to protect the persons who negotiate. It does not necessarily indicate - as it is often believed - an intention to surrender'. ${ }^{112}$

The UK's Manual on the Law of Armed Conflict is interesting because it equivocates as to whether the white flag expresses an intention to surrender, epitomising the lack of clarity as to the status of the white flag under international humanitarian law. Initially, the Manual explains that: ${ }^{113}$

From time immemorial, a white flag has been used as a signal of a desire to open communications with the enemy. This is the only meaning that the white flag possesses in the law of armed conflict ... The display of a white flag means only that one party is asked whether it will receive a communication from the other.

The Manual then proceeds to explain that '[e]verything depends on the circumstances and conditions of the particular case. For instance, in practice, the white flag has come to indicate surrender if displayed by individual soldiers or a small party in the course of an action' ${ }^{114}$

In light of this disagreement, Henderson is surely correct in his assertion that ' $[\mathrm{t}]$ he flying of a white flag is not a definite symbol of surrender'. ${ }^{115}$

\footnotetext{
${ }^{108}$ US Law of War Manual (n 68) para 5.9.3.2. (underscore in the original).

109 ibid para 12.4.1.

${ }^{110}$ US Law of Armed Conflict Deskbook (n 60) 167.

${ }^{111}$ Canada, Code of Conduct for CF Personnel (Office of the Judge Advocate General 2001) r 5 para 3.

${ }^{112}$ Côte d'Ivoire, Droit de la guerre, Manuel d'instruction, Ministère de la Défense, Forces Armées Nationales (2007) 46-47.

${ }^{113}$ United Kingdom, Joint Service Manual of the Law of Armed Conflict (2004) paras 10.5-10.5.1.

114 ibid para 10.51 .

${ }^{115}$ Henderson (n 55) $88 \mathrm{fn} 64$. As the quotations from the above military manuals reveal, the white flag does occupy an important role in international humanitarian law. Art 32 of the Hague Regulations 1907 (n 48) provides that persons who cross the battlefield in order to conduct negotiations with the opposing force cannot be made the object of attack from the moment they assume this role until the moment it is concluded. Such persons are known as parlementaires. A request to advance across the battlefield to enter into negotiations is made by waving the
} 
One final question remains. Does the act of retreat amount to conduct that signals an intention to surrender under either treaty or customary international law? Neither treaty law, including the relevant commentaries, nor military manuals indicate that retreat is indicative of surrender. This issue is relevant because during the First Gulf War, American forces overran Iraqi troops near the KuwaitIraq border and American forces continued to directly target Iraqi forces even though they were in clear retreat. The US military was criticised for this conduct. ${ }^{116}$ In responding to these criticisms, the US Department of Defence submitted a report to Congress, which maintained that the act of retreat does not amount to a positive act that clearly reveals an intention to surrender: ${ }^{117}$

It is recognized by military professionals that a retreating force remains dangerous. The 1st Marine Division and its 4,000 attached U.S. Army forces and British Royal Marines, in the famous 1950 march out of the Chosin Reservoir in North Korea, fighting outnumbered by a 4:1 margin, turned its 'retreat' into a battle in which it defeated the 20th and 26th Chinese Armies trying to annihilate it.

The US Law of War Manual reiterates this view: 'Enemy combatants remain liable to attack when retreating. Retreat is not the same as surrender. Retreating forces remain dangerous as the enemy force may recover to counterattack, consolidate a new defensive position, or assist the war effort in other ways'. ${ }^{118}$ This view is also endorsed by the ICRC, which explains that ' $[t]$ he law of armed conflict does not prohibit attacks on retreating enemy forces. At the level of small units, for example, once an objective has been seized, an attacking force is trained to fire on the retreating enemy to discourage or prevent a counterattack'. ${ }^{119}$ As a result, state practice makes it 'clear that the simple fact that troops are retreating does not demonstrate an intent to surrender'. ${ }^{120}$

\subsection{Is It Reasonable in the Circumstances for the Opposing Force to Discern the OFFER OF SURRENDER?}

Surrender is a legal exchange constituted by a valid offer and its subsequent acceptance. ${ }^{121}$ Where a person engages in a positive act that reveals to the opponent that he or she no longer intends to

white flag, which then must either be accepted or rejected by the opposing force. For a discussion of the legal framework relating to parlementaires see Leslie Green, The Contemporary Law of Armed Conflict (Manchester University Press 2013) 113-16.

${ }^{116}$ Patrick E Tyler, 'War in the Gulf: The Overview; Iraq Orders Troops to Leave Kuwait but US Pursues Battlefield Gains; Heavy American Toll in Scud Attack', The New York Times, 26 February 1991, http://www. nytimes.com/1991/02/26/world/war-gulf-overview-iraq-orders-troops-leave-kuwait-but-us-pursues-battlefield. html?pagewanted=all.

${ }^{117}$ US Department of Defense (n 77) 644.

${ }^{118}$ US Law of War Manual (n 68) para 5.4.6.3. (footnotes omitted).

${ }^{119}$ ICRC, The Law of Armed Conflict: The Conduct of Operations: Part A, June 2002, 19, https://www.icrc.org/ eng/assets/files/other/law3_final.pdf.

${ }^{120}$ William Fenrick, 'Specific Methods of Warfare' in Elizabeth Wilmshurst and Susan Breau (eds), ICRC Study on Customary International Humanitarian Law (Cambridge University Press 2007) 141.

121 'Surrender involves an offer by the surrendering party (a unit or an individual solider) and an ability to accept on the part of his opponent': US Department of Defense (n 77) 641. 
directly participate in hostilities, the opposing force is legally obligated to accept that offer of surrender and refrain from making such a person the object of attack. ${ }^{122}$

An interesting incident came to light in October 2010 as a result of classified US military logs being published by the whistle-blower website Wikileaks. ${ }^{123}$ The logs revealed that during the Second Gulf War a US Apache helicopter engaged a truck containing two Iraqi insurgents. The US pilots then radioed military headquarters, explaining that the two insurgents 'came out [of the truck] wanting to surrender'. ${ }^{124}$ Military headquarters subsequently communicated to the pilots the legal advice of a US military lawyer: 'Lawyer states they cannot surrender to aircraft and are still valid targets'. ${ }^{125}$ The Apache helicopter opened fire on the insurgents, eventually killing them both. Commenting upon the incident, Roberts correctly notes that while '[s]urrender is not always a simple matter', the legal advice of the US military lawyer that ground forces cannot surrender to aircraft, and thus offers of surrender in such circumstances can be permissibly refused was 'dogmatic and wrong' ${ }^{126}$ Roberts further notes that ' $[t]$ he issue is not that ground forces simply cannot surrender to aircraft. The issue is that ground forces in such circumstances need to surrender in ways that are clear and unequivocal'. ${ }^{127}$ Where a valid offer of surrender is communicated to an opponent, there is a legal obligation upon the opponent to accept that offer and to refrain from making surrendered persons the object of attack.

In light of the fog of war that inevitably (and often densely) hangs over armed conflict, it may be the case that an enemy expresses an intention to surrender but the circumstances existing at the time prevent the opposing force from discerning that offer of surrender. During the First Gulf War, US tanks equipped with earthmoving plough blades breached Iraqi defences and then turned and filled in trenches, entombing Iraqi soldiers who had sought to surrender. A US report into the incident explained: ${ }^{128}$

[The opponent] may not refuse an offer of surrender when communicated, but that communication must be made at a time when it can be received and properly acted upon - an attempt to surrender in the midst of a hard-fought battle is neither easily communicated nor received. The issue is one of reasonableness.

The report continues: ${ }^{129}$

[A] soldier who fights to the very last possible moment assumes certain risks. His opponent either may not see his surrender, may not recognize his actions as an attempt to surrender in the heat and confusion

122 'The law of war obligates a party to a conflict to accept the surrender of enemy personnel': ibid.

${ }^{123}$ David Leigh, 'Iraq War Logs: Apache Crew Killed Insurgents Who Tried to Surrender', The Guardian,

22 October 2010, https://www.theguardian.com/world/2010/oct/22/iraq-war-logs-apache-insurgents-surrender.

124 ibid.

125 ibid.

${ }^{126}$ Professor Sir Adam Roberts, quoted in Leigh (n 123).

127 ibid.

${ }^{128}$ US Department of Defense (n 77) 641.

129 ibid 643. 
of battle, or may find it difficult (if not impossible) to halt an onrushing assault to accept a soldier's last minute effort to surrender.

Thus, the test imposed by international humanitarian law is whether a reasonable combatant operating in those circumstances would have been expected to discern the offer of surrender. This approach is consistent with the obligation arising under the law of international ${ }^{130}$ and noninternational $^{131}$ armed conflict that, when launching an attack, combatants and fighters must take all feasible precautions to avoid or minimise damage to non-military objects such as civilians and those hors de combat. ${ }^{132}$ What are feasible precautions is difficult to define but Article 3(4) of the Convention on Conventional Weapons $1980^{133}$ describes them as 'those precautions which are practicable and practically possible taking into account all circumstances ruling at the time, including humanitarian and military considerations'.

To illustrate, it may not be reasonable or feasible to expect a combatant or fighter who engages his or her enemies at speed and at night to identify an offer of surrender and, as a result, refrain from making them the object of attack. This conclusion may be different in a scenario where a commander has his or her enemy pinned down and the enemy decides to surrender but, for various reasons (such as distance between the respective parties, inimical terrain, inclement weather), the offer of surrender is not immediately apparent to the opposing commander. International humanitarian law nevertheless requires the commander to take all reasonable and feasible measures to ensure that the targets remain permissible objects of attack before launching an offensive. It may be reasonable, for example, for the commander to utilise readily available equipment (such as night vision goggles or high performance binoculars) to check whether the enemy has expressed an intention to surrender before they are engaged, provided, of course, that the time spent preparing the equipment or using it does not compromise military objectives.

All in all, the point is that even if an offer of surrender is validly extended under international humanitarian law, if that offer cannot reasonably be discerned in the circumstances then, from the perspective of the opposing force, the threat represented by the enemy remains and the principle of military necessity continues to justify their direct targeting.

\footnotetext{
${ }^{130}$ Additional Protocol I (n 6) art 57(1). Its customary status during international armed conflict is confirmed by ICRC Study (n 6) r 15.

${ }^{131}$ Additional Protocol II (n 49) art 13(1). Its customary status during non-international armed conflict is confirmed by ICRC Study (n 6) r 15.

${ }^{132}$ Although $\mathrm{r} 15$ of the ICRC Study (n 6) requires precautions to be taken to avoid or minimise 'incidental loss of civilian life, injury to civilians and damage to civilians', $r 15$ should be read as an obligation to avoid or minimise harm to non-military objects generally (including those hors de combat). This is the requirement of Additional Protocol I (n 6) art 57(2)(a)(i), which explains that 'those who plan or decide upon an attack shall do everything feasible to verify that the objectives to be attacked are neither civilians nor civilian objects and not subject to special protections but are military objectives within the meaning of paragraph 2 of Article 52 and that it is not prohibited by the provisions of this Protocol to attack them'.

${ }^{133}$ Convention on Prohibitions or Restrictions on the Use of Certain Conventional Weapons which may be deemed to be Excessively Injurious or to have Indiscriminate Effects (as amended 21 December 2001) (entered into force 2 December 1983) 1342 UNTS 137.
} 


\subsection{Have the Persons Surrendering Unconditionally Submitted to the Authority of THeIR OPPONENT?}

Article 41(2) of Additional Protocol I and Rule 47 of the ICRC Study stipulate that a person who surrenders but subsequently engages in a 'hostile act' or 'attempt[s] to escape' is no longer regarded as hors de combat and again becomes liable to direct targeting. ${ }^{134}$ While the notion of attempting to escape is relatively self-explanatory, what constitutes a hostile act is far from clear. Additional Protocol I does not define what amounts to a hostile act but the Commentary to the Additional Protocol provides examples, such as resuming combat functions if the opportunity arises, attempting to communicate with their own party, and destroying installations and equipment belonging to their captor or to their own party. ${ }^{135}$

State practice points towards a broad reading of the notion of what is a hostile act. State practice indicates that a surrendered person who fails to comply unconditionally with the instructions of the opposing force commits a hostile act and thereby forfeits immunity from targeting ${ }^{136}$ - in other words, surrendered persons must place themselves 'at the captor's discretion'. ${ }^{137}$ The act of surrender, therefore, is a continuing obligation insofar as the persons surrendering must continually comply with the demands of their captor. Thus, persons who refuse to obey demands to kneel or to lie on the ground, place their hands behind their back, remain silent, stand still and so on, do not submit to the authority of their opponent and do not surrender for the purpose of international humanitarian law. Presumably, surrendered persons have only to comply with reasonable demands of their captor: captors cannot require their captives to undertake conduct that exposes them to danger and, if they refuse to comply, determine that they have committed a hostile act and are therefore liable to attack. Certainly, a captor cannot demand captives to act incompatibly with international humanitarian law (such as ordering them to shoot civilians or instructing them to act in a way that is in contravention of their legal rights as prisoners of war) and, if these demands are not complied with, determine that they have engaged in a hostile act and can be thus made the object of attack.

By way of illustration, during the Falklands Conflict the Director of the United Kingdom (UK) Army Legal Services stated that where enemy combatants had surrendered but UK armed forces continued to come under fire from other enemy combatants, UK forces were entitled to remain in their positions and demand that surrendered persons advance forward. Failure to adhere to such demands - provided they were reasonable in the sense that they did not place the surrendering forces in danger of being caught in crossfire - would constitute

\footnotetext{
${ }^{134}$ The US Law of War Manual explains that '[a]11 hostile acts or resistance, or manifestations of hostile intent, including efforts to escape or to destroy items, documents, or equipment to prevent their capture by the enemy', vitiate an otherwise legally effective surrender: US Law of War Manual (n 68) para 5.9.3.2.

${ }^{135}$ Sandoz, Swinarski and Zimmermann (n 1) paras 1621-22.

136 'The offer to surrender must be clear and unconditional': US Law of War Manual (n 68) para 5.9.3.2.

${ }^{137}$ The US explains that '[s]urrender may be made by any means that communicates the intent to give up. No clear rule exists as to what constitutes surrender. However, most agree surrender means ceasing resistance and placing oneself at the captor's discretion': US Law of Armed Conflict Deskbook (n 60) 138. See also Hague Regulations IV (n 48) art 23(c): 'It is forbidden [t]o kill or wound an enemy who ... has surrendered at discretion'.
} 
unwillingness to submit themselves to the authority of their captor and would therefore vitiate their surrender, which means that they would remain permissible objects of attack under international humanitarian law. ${ }^{138}$

In sum, persons who demonstrate an intent to surrender create a rebuttable presumption that they are hors de combat and no longer a threat to the enemy. Persons who attempt to escape or commit a hostile act - which means that they fail to submit to the authority of their opponent indicate that they are resuming participation in hostilities. As a result, they re-emerge as a threat to military security and the opposing force is justified in making them the object of attack.

\section{Conclusion}

The obligation to accept offers of surrender and to refrain from directly targeting persons who have surrendered is justified on the basis that there is no military necessity to target those who no longer intend to participate in hostilities, and that such conduct represents an unacceptable affront to human dignity. This article has explored state practice with the aim of clarifying the criteria that give rise to an effective act of surrender under conventional and customary international humanitarian law in times of international and non-international armed conflict.

The contribution of this article has been to propose a tripartite test for determining the type of conduct that constitutes an act of surrender and thus imposes a legal obligation upon opposing forces to cease fire: (1) Have surrendering persons engaged in positive acts that clearly indicate that they are outside the theatre of war and therefore no longer represent a threat to the opposing force? (2) Is it reasonable in the circumstances for the opposing force to discern the offer of surrender? (3) Have the persons surrendering unconditionally submitted themselves to the authority of their captor?

Perhaps the thorniest issue is what positive act (or acts) are recognised by international humanitarian law as expressing an intention to surrender. From a survey of military manuals I have revealed that the laying down of weapons and the raising of hands is a widely accepted method of indicating such an intention under both conventional and customary international humanitarian law. Contrary to popular belief, the waving of a white flag is not a legally recognised method of expressing an intention to surrender under either conventional or customary international humanitarian law - it does not attract sufficient support within state practice and, indeed, the practice of a number of states openly rejects the contention that the waving of a white flag is constitutive of surrender.

It is therefore concerning that a number of military manuals erroneously identify the white flag as a sign of surrender under international humanitarian law. In doing so, these manuals incorrectly instruct their armed forces to recognise that those who wave a white flag cannot be attacked

\footnotetext{
${ }^{138}$ Report on UK Practice, 1997, Notes of a Meeting with a Former Director of Army Legal Services, 19 June 1997, Ch 2.1, cited in Jean-Marie Henckaerts and Louise Doswald-Beck (eds), Customary International Humanitarian Law, Vol II: Practice (International Committee of the Red Cross (ICRC) and Cambridge University Press 2005) 975.
} 
and that, by implication, if they themselves wish to surrender, the waving of a white flag is an effective method of manifesting this intention to the enemy. Given the importance of surrender to realising the humanitarian objective that underpins international humanitarian law, this legal framework must embrace a common vernacular that enables those embroiled in armed conflict to engage in conduct with the confidence that it is a recognised method of expressing an intention to surrender. The status and function of the white flag is clearly an area that requires urgent clarification by states and the international community as a whole, and this article has sought to catalyse this process and contribute to it. ${ }^{139}$

\footnotetext{
${ }^{139}$ Incidentally, under international humanitarian law (including the law of international and non-international armed conflict (see Additional Protocol I (n 6) art 37(1) and ICRC Study (n 6) r 65) and international criminal law (during both international and non-international armed conflict - see respectively ICC Statute (n 51) art $8(2)(\mathrm{b})(\mathrm{xi})$ and $8(2)(\mathrm{e})(\mathrm{ix}))$ it is unlawful to invite the confidence of adversaries with the purpose of injuring or capturing them. Such conduct is known as perfidy. It is well established that feigning surrender in order to invite the confidence of an enemy is a perfidious act. Resolving the question of the type of conduct that expresses an intention to surrender would therefore produce the collateral benefit of also clarifying the rule relating to perfidy.
} 